„Kwartalnik Filmowy” no. 116 (2021)

ISSN: 0452-9502 (Print) ISSN: 2719-2725 (Online)

https://doi.org/10.36744/kf.961

(c) Creative Commons BY-NG-ND 4.0

Fabio Bego

independent researcher

https://orcid.org/oooo-0003-3339-9997

\title{
On Authenticity and Popular Culture
}

\author{
Keywords: \\ popular culture; \\ authenticity; \\ popular music; \\ subcultures
}

\begin{abstract}
In the review the author analyses Ewa Mazierska's book Polish Popular Music on Screen (2020), which investigates the mutually entangled histories of Polish politics, cinema, TV, and music. Although it focuses on the Polish context, the general and theoretical observations that emerge from Mazierska's analysis relate also to the broader former socialist Europe. Departing from Mazierska's work, the author tackles the question of "(in)authenticity" in relation to popular culture. The word "authenticity" often appears in the text to express the critics' opinions of cultural products, but it is not clearly defined. The review of Mazierska's research starts with a preliminary analysis of the concept, which enables a transversal discussion of the data presented in the text. Then the author draws some conclusions about the current state of research on Eastern European culture by highlighting the limits and the potentials of the field.
\end{abstract}




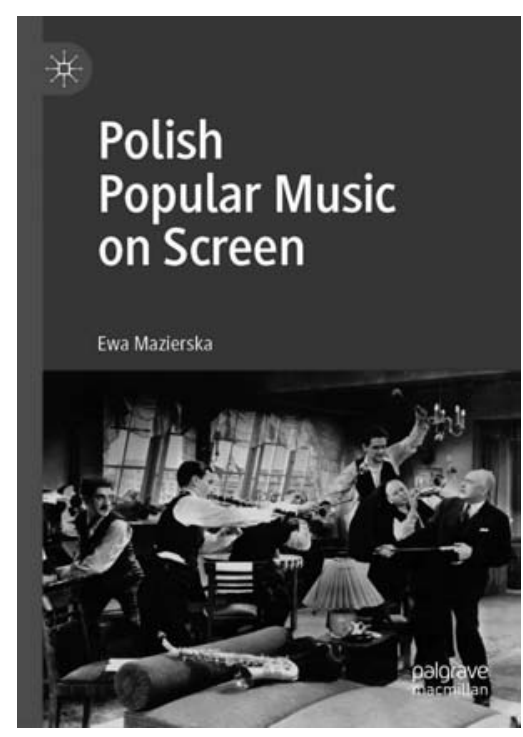

Ewa Mazierska's research aims at filling a gap in the knowledge of Eastern European popular culture and at reviewing the epistemological issues that have conditioned the understanding of this topic. Her recent work Polish Popular Music on Screen investigates the entangled histories of Polish politics, cinema, TV, and music.

Mazierska's study comprises four parts, which explore the use of popular music in Polish musicals, cinema and TV biopics with or about musicians, music documentaries, and music videos that have been released in Poland. It spans the major period between the inter-war years and the YouTube era. The narrative unfolds diachronically, and each part can be read separately. The book has gathered a significant amount of information about internationally less-known films, directors, actors, composers, musicians, bands and TV producers active in Poland from the onset of the sound film era to the present days.

The information contained in the book suggests a dialectic between what artists, audiences and critics perceive to be authentic and inauthentic forms of music and films/videos. The word "authentic" is often evoked in the text in order to express the qualities of this cultural production, but Mazierska does not provide a clear definition of the term. The first part of this review is dedicated to the investigation of the relations between authenticity and popular culture in response to Mazierska's use of the term. I then check how the notions that emerge from the analysis apply to Mazierska's presentation of Polish popular culture.

\section{Authenticity and Popular Culture}

What is it that makes a particular kind of music or film worthy of critical acclaim and academic interest? Certainly originality - a feature that, according to critics cited by the author, popular films and music do not have. Mazierska's research suggests that one of the first things that academics and critics look for when they try to establish the authenticity of a given cultural product is whether the identity of the work of art is coherent with the spatial and historical context in which it was originally produced. For this reason, cultural trends such as rock music that are associated with the West seem not to be original when performed by Eastern European bands. This bias emerges in films and documentaries analysed by Mazierska, such as To tylko rock (This is Only Rock, 1984) by Paweł Karpiński and Beats of Freedom - Zew wolności (Beats of Freedom, 2010), directed by Leszek Gnoiński and Wojciech Słota.

There are also other reasons why popular culture is considered inauthentic. Polish critics labelled musical films with the derogatory term muzykol (p. 57). Pop and rock events such as Sopot and Opole festivals were criticized for their low quality and because they diverted people from political activities (p. 214). Disco 
Polo, the Polish version of the 1990s Eurodance genre, was considered a disease (p. 117). These judgments do not concern originality in the spatial-temporal sense, but rather the social and political functions of the work of art. Mazierska reports that the negative opinions that Polish critics expressed about popular culture reflect Adorno's distinction between serious and popular music (p. 7). According to the German philosopher, the latter is characterized by standardization and imitation. Adorno described the audience of popular music as robots that were both consumers and products of a political system that kept them enslaved. ${ }^{1}$

Adorno's reflection on music can be extended to films. Drawing on his thought and on the critical judgments cited by Mazierska, mass consumption seems to be one of the main reasons why popular music and films are considered inauthentic. This aspect emerges also in Walter Benjamin's essay "The Work of Art in the Age of Mechanical Reproduction". According to him, authenticity is determined by the 'here and now' of the artwork, that is the existence of the original in a unique place. One of the consequences of mechanical reproduction is that art is no longer carefully contemplated by individuals, but it is absorbed by distracted masses such as cinema spectators. ${ }^{2}$

Benjamin suggests that mechanical reproduction has displaced works of art from the religious to the profane sphere of everyday sociality. The rootedness of popular culture in everyday sociality de-authenticates cultural products, because no-one can claim their authorship. The material evoked by Mazierska seems to corroborate this view. Early music videos transmitted by Polish state TV and more recent YouTube videos do not contain information about directors (p. 273). The anonymity of popular culture can in part be explained, as Mazierska points out, by the fact that TV programmes are not considered works of art.

This attitude toward TV broadcasts and popular culture in general probably springs from the fact that authorship cannot be attributed to a product made for anonymous masses. Authors of popular films and music can here be analysed through Heidegger's description of the everyday Dasein (human being). According to Heidegger, everyday sociality (being-with-the-others) is an inauthentic form of existence, because it is dominated by the others. These others are not definite others and are no-one in particular, they are the they ${ }^{3}$ (das Man). Filmmakers and composers are expected to make products that will be understood by the largest possible crowd of people. In order to satisfy a range of 'average' tastes, they must think like everyone in general and no-one in particular. Popular culture can have no authorship, because it is a product of 'averageness'. From this perspective popular music and films can be put in the same category as public benches or manhole covers.

Beside the questions of origin, standardization, and authorship, popular films and music are often de-authenticated by the fact that they are made to make money and not to improve artistic expression or tackle relevant social issues. Mazierska reports that box office hits were derided by Polish critics, because they were considered conformist and pandering to the low taste of the audience (p. 61). In the 1930s, producers of musicals were named branża (professionals) in order to denote their business-oriented style of production. The concept shares some similarities with the term "exploiteer", which has been coined to define producers or directors of American exploitation films who were animated by a similar entrepreneurial spirit. ${ }^{4}$ 
Expanding on the information provided by Mazierska and considering Benjamin's conceptions of inauthenticity, it can be said that Polish critics do not value popular cultural products, because mass production accentuates the profanation of art. Moreover, if cultural production is moved by profit, it implies that the author must satisfy the tastes of the indefinite others that have, in turn, suppressed the author's creative drives. Finally, profit-oriented cultural production generates ethical issues related to the political economy of capitalism. The selling of popular culture can compromise social justice that depends on the balanced distribution of resources.

\section{Popular culture and the state}

Mazierska shows that the state, and in particular the socialist state, has invested in the production of popular culture and has promoted its reception by the audiences. With the advent of state-socialism in the aftermath of World War II, all films (and, by extension, all cultural products) became by definition popular, because they were addressed to the whole of society (p. 1). Like in other Eastern European countries, Polish popular culture was inspired by Romanticism on the one hand and by socialist realism on the other (p. 155). In cinema, the realist component was dropped in the 1950s, but these influences in art and culture persisted. A more careful investigation of the concept of authenticity would have allowed the author to explore the way in which the term "people" is used to empower the anonymous masses.

Socialist institutions could not consider the culture of the people - which was the source of sovereign power - as a thing without artistic or moral values. Socialist society could not be described as an inauthentic form of sociality but as the path chosen by the people's resolute will. The people, in this case the Polish people, is the 'author' of Polish culture and everything that bears its signature is original and authentic. The identification of particular cultural products with a precise 'ethnic' context of origin occurs each time one claims that a certain song or music genre comes from a specific country. Drawing on Mazierska's analysis, I believe that associating popular culture with a specific ethnic milieu might be an outcome of methodological nationalism. Many researchers consider the United States and the United Kingdom as the main originators of contemporary popular cultural trends. However, this opinion does not take into consideration the cultural exchanges that occurred during the colonial history of Europe and North America.

In Poland, like in other Eastern Bloc countries that carried out class struggle, everything was virtually produced by the people. Political authorities tried to erase formal differences between serious, popular and folk music (p. 8), and also needed to find the right ways to represent the artists as exponents of the people. The work and the attitudes of the artists could not be then portrayed as the outcome of the average behaviours. A popular artist needed to be typical, but not an average character. In the words of Georgy Malenkov cited by Mazierska, the term "typical" did not mean that which is encountered most often, but that which most persuasively expresses the essence of a given social force (p. 154). In analogy to their Soviet colleagues, Polish filmmakers focused on the production of socio-biographies in which both the artists and the community appear to be fully involved in the historical events that they experienced. 
Beside folk and classical composers, Polish institutions also authenticated rock music. The state TV transmitted music videos of Polish rock bands since the late 1960s, when the so-called big beat genre became popular in the country. For example, in the video of the song "Gdybyś kochał, hej" ("If You Loved Me, Hey", 1969) by the band Breakout, rock music is combined with lyrical metrics and Polish folk imagery (p. 275-276). The song has some similarities with Jimmy Hendrix's version of "Hey Joe", such as part of the guitar riffs. In my opinion, this resemblance should not be considered as an attempt to copy the song, but as a deliberate reference to a rock classic. A similar endeavour to domesticate rock music also appears in "Kulig" ("Sleigh Ride", 1968), a music video 'combine', as Mazierska calls it. She claims that the video was made to prove that rock music and rock lifestyle are innocuous and can coexist with different cultures: pop, folk and archaic (p. 279). Unlike other videos of the same period, "Sleigh Ride" was signed by the director Stanisław Kokesz. This detail denotes an attempt to emphasize the uniqueness of the work.

Notwithstanding the effort, according to Mazierska, the socialist state could not blur differences between serious and popular culture, and the latter could not be fully authenticated. In the cinema context, this process was in part due to the system of production that generated two types of directors: those who had enough autonomy to produce auteurist films and others who made films about everyday life (p. 3-4, 71). Differences between popular and serious culture also remained, because, contrary to Gramsci's predictions, the working class did not obtain the cultural hegemony. Mazierska explains that the middle class (she does not use this term, though) reproduced itself through cultural capital (p. 11). For instance, Tomasz Beksiński, whose tragic story was later portrayed in two documentaries, became a cult music journalist in Poland thanks to a record collection that he gathered with the help of his father, the famous painter Zdzisław Beksiński, who was in the position to import them from abroad (p. 178).

\section{Mazierska's take on "authenticity"}

Mazierska's take on Polish popular music on screen relies on the methods of historical investigation, art criticism and participant observation. She does not judge films or videos on account of pre-established categories, but according to the way in which the plots are coherent with the social dynamics that they want to represent. The lack of familiarity with the social and cultural contexts is one of the major faults in films about popular musicians and bands, such as Skazany na bluesa (Destined for Blues, 2005) by Jan Kidawa-Błoński or Czerwone Gitary... i pół wieku (Red Guitars... and Half a Century, 2015) by Maciej Wróbel. The same weakness is found in films and documentaries about the Disco Polo scene, which - according to Mazierska - still awaits appraisal because it has never been narrated by insiders' voices (p. 125).

Most of the works analysed by Mazierska have failed to authentically represent the social contexts and the characters that they tried to portray. There are, however, a few exemptions, such as Marek Piwowski's documentary about the singer Czesław Niemen, Sukces (Success, 1969), and the biopic Jesteś Bogiem (You Are God, 2012) by Leszek Dawid. The latter film tells the story of Magik, former member of the hip hop band Paktofonika, who committed suicide at a very young age. Drawing on Mazierska's account, this work has successfully portrayed the 
crew's history, not so much due to the conventional "authentication" techniques used by the director, but because he has grasped the way in which music moulded the world of the protagonists. As Mazierska put it, Dawid put faith in music as a narrative tool, as opposed to seeing it only as an embellishment or an addition to the narrative (p. 176).

Mazierska's research offers important insights into the way in which popular culture is produced and disseminated. This information is usually contained in the beginning of each section of the book in order to explain the interaction between the cultural industry and the social and political environment that characterized Poland in different historical periods. The potential of this research path becomes visible when Mazierska describes the activities of the Chairman of the Television and Radio Committee Maciej Szczepański and the TV producer and film director Janusz Rzeszewski (p. 91-92). The stories of Szczepański and Rzeszewski show that in the 1970s, the entertainment sector introduced technologies and deployed communication strategies that anticipated the political transformations of the 1980s. This part of the research lacks the support of archival material that would have probably provided deeper knowledge of the political and social dynamics that characterized the relations between the Polish government(s) and highrank agents of the cultural field.

\section{Potential for further research}

The cultural industries of former Eastern Bloc countries is an underrated topic that, if appropriately studied, might contribute to changing conceptions about the relation between politics and culture before, during and after the Cold War. One of the most intriguing part of Mazierska's book is the analysis of the way in which the socialist regime positioned itself in relation to cultural trends and events that could have been potentially threatening to the status quo, such as the Jarocin Festival. Mazierska portrays the event in a different way than Piotr Łazarkiewicz in the documentary Fala (The Wave, 1986). For her, the festival was not so much the terrain of generational conflict as a venue for young people to meet and for the local authorities to put the small town on the map (p. 220); however, it served as a safety valve [for the state], allowing disgruntled youth to express their grievances in the limited time and space of a 'carnival' (p. 218). Earlier in the book, the author cites Gregory Kveberg's claim that $a$ belief in the need to spread culture and raise the cultural level of the audience linked conservative Soviet officials and many key figures of the underground (p. 11). A similar dynamic also occurred in socialist Albania, where the government tried to promote cultural grassroots activism. The fields of intervention varied from the popular music scene $^{5}$ to remote frontier areas where the government promoted cultural movements for the defence of the border through training, games and music. ${ }^{6}$

The collusion between institutions and 'underground' culture is a crucial aspect of Western and Eastern European popular culture both before and after the end of the Cold War. Mazierska's book shows that more research is necessary to understand how the state and/or capital de-authenticates peculiar musical trends and countercultural scenes and identities. One of the most important contribution of her work consists in drawing attention to Eastern European subcultures such as techno, punk, and hip-hop scenes. Scholars are mostly interested in regional 
subcultures when the latter reflect their stereotyped views on Eastern Europe. There are fewer publications about punk (and its various articulations), metal, hiphop, techno, and other music-centred underground scenes, than there are studies and reports about football hooliganism, far-right groups, and religious extremism.

This discrepancy is not determined by the fact that religious and political extremism has more subversive force than music or art-based subcultures. Underground circles are often persecuted and demonized by governments and the media because they contend spaces and crowds to institutionalized art. Lack of academic interest in regional underground scenes is partly explained by the long-term effects of colonial ideology, according to which Eastern Europe is an area where to look for traditions, that is the past, and not for the contemporary.

Postcolonial scholarship has inhibited research on regional underground scenes because the (cultural) colonization of the East by the West is considered a one-way irreversible process that prevents Eastern Europeans from engendering original contemporary cultural trends. The belief that Eastern Europe is a cultural milieu where the past prevails over the present is indicated by the fact that scholars have been particularly interested in the electronic-ized folk music that became popular in the 1990s, ${ }^{7}$ whereas other genres that emerged in the same period have only recently started to be systematically investigated. ${ }^{8}$

An interesting line of enquiry for further scholarship could focus more on what music represents for its fans and other art-based subcultures. In these cases, music is an intimately cultivated interest that has a profound impact on a person's social relations, networks, political opinions, affects and desires. Reading Mazierska's book, I had the impression that she tends to downplay the social and political role of music by considering it as having mostly entertainment functions. Music is not only enjoyed in leisure time, but it accompanies peoples' everyday life, as in the case of the characters appearing in Paktofonika's videos. Listening to a track on the headphones, at a gig or on TV has a significant role in attuning us with the environment and with the others.

Being part of a movement that evolves around music contributes to recovering a sense of social, political and cultural agency whose loss one may realize only after accessing these alternative forms of socialization. Moreover, since subcultural products are promoted and distributed within a limited range of social circles, participating in live shows or having access to productions that are not known or appreciated by larger crowds contributes to restoring the ritualistic function of art and to generate a more personal form of contemplation. The combined process of music and video production as well as event organization and promotion generate new spaces of social, political and economic relations. People who affiliate with subcultures usually feel to be living an 'authentic' life, because they believe that they have chosen the things they do by rejecting mainstream culture.

Further research is necessary to understand whether underground culture can be termed popular without being mainstream. Polish Popular Music on Screen has shown that the borders between underground and mainstream (sub)cultures are blurred by the internet, which makes any cultural product potentially available to everyone, and by the technologies that have eased and homogenized the process of music and film production. However, one of the main features that distinguishes music-based subcultures from the mainstream is the tendency of the former to con- 
ceal the scene rather than exposing it, despite the fact that productions are often made available online for free and access to live shows is cheap or free. Further research might provide a more in-depth analysis of the way in which digitalization, social media, YouTube channels and other online platforms have altered the relationship between mainstream and underground circles, as well as their impact on the attitudes and expectations of underground filmmakers and composers or producers. Finally, a comparative investigation of the institutional attitudes toward art-based subcultures might provide an interesting picture of the recent history of underground music and film scenes in different European countries, which will, in my view, reframe the inveterate opinion that Eastern Europe has been the less creative side of the continent.

Ewa Mazierska, Polish Popular Music on Screen, Palgrave Macmillan, Cham 2020.

${ }^{1}$ T. W. Adorno, “On Popular Music", in: Cultural Theory and Popular Culture: A Reader, ed. J. Storey, The University of Georgia Press, Athens 1998, p. 205.

${ }^{2}$ W. Benjamin, "The Work of Art in the Age of Mechanical Reproduction", trans. H. Zohn, in: Illuminations, ed. H. Arendt, Schocken Books, New York 1969, p. 217-251.

${ }^{3}$ M. Heidegger, Being and Time: A Translation of "Sein und Zeit", trans. J. Stambaugh, State University of New York Press, Albany 1996, p. 119.

${ }^{4}$ See E. Schaefer, "Bold! Daring! Shocking! True!": A History of Exploitation Films, 1919-1959, Duke University Press, Durham 1999.

${ }^{5}$ N. Tochka, Audible States: Socialist Politics and Popular Music in Albania, Oxford University Press, New York 2016, p. 99.
${ }^{6} \mathrm{~F}$. Bego, La frontiera come dittatura e dissidenza: Culto e fuga tra l'Albania comunista e la Jugoslavia - paper delivered at the conference "Frontière" (Sorbonne University, Paris 1 - June 19, 2015), unpublished.

${ }^{7}$ See Balkan Popular Culture and the Ottoman Ecumene: Music, Image, and Regional Political Discourse, ed. D. A. Buchanan, The Scarecrow Press, Lanham 2007.

${ }^{8}$ See Hip Hop at Europe's Edge: Music, Agency, and Social Change, eds. M. Miszczynski, A. N. Helbig, Indiana University Press, Bloomington 2017.
Fabio Bego
Scholar specializing in the study of nationalism, statebuilding and the Balkans. He has studied Anthropology and International Relations in Rome before obtaining a PhD in European and International Studies at the Roma Tre University (2017). He has published several articles on the relations between Albanians and their Balkan and Italian neighbours. Curator of the Albanian Film Festival "Albania, si Gira!" held in Rome. 


\section{Bibliography}

Adorno, T. W. (1998). On Popular Music. In: J. Storey (ed.), Cultural Theory and Popular Culture: A Reader (pp. 197-209). Athens: The University of Georgia Press.

Benjamin, W. (1969). The Work of Art in the Age of Mechanical Reproduction (trans. H. Zohn). In: H. Arendt (ed.), Illuminations (pp. 217-251). New York: Schocken Books.

Buchanan, D. A. (ed.) (2007). Balkan Popular Culture and the Ottoman Ecumene: Music, Image, and Regional Political Discourse. Lanham: The Scarecrow Press.

Heidegger, M. (1996). Being and Time: A Translation of "Sein und Zeit" (trans. J. Stambaugh). Albany: State University of New York Press.

Mazierska, E. (2020). Polish Popular Music on Screen. Cham: Palgrave Macmillan.

Miszczynski, M., Helbig, A. N. (eds.) (2017). Hip Hop at Europe's Edge: Music, Agency, and Social Change. Bloomington: Indiana University Press.

Schaefer, E. (1999). "Bold! Daring! Shocking! True!": A History of Exploitation Films, 1919-1959. Durham: Duke University Press.

Tochka, N. (2016). Audible States: Socialist Politics and Popular Music in Albania. New York: Oxford University Press.

Słowa kluczowe:

kultura popularna; autentyczność; muzyka popularna; subkultury

\section{Abstrakt \\ Fabio Bego \\ O autentyczności i kulturze popularnej}

Autor recenzuje książkę Polish Popular Music on Screen (2020) Ewy Mazierskiej, która w swej pracy śledzi wzajemne uwikłania historyczne polskiej polityki, kina, telewizji i muzyki. Mimo że autorka skupia się na kontekście polskim, pojawiające się w jej analizie obserwacje ogólnoteoretyczne dotyczą również szerzej rozumianej dawnej Europy socjalistycznej. Wychodząc od książki Ewy Mazierskiej, recenzent stawia pytanie o „(nie)autentyczność” w odniesieniu do kultury popularnej. Słowo „autentyczność” jest przez autorkę często stosowane dla wyrażenia opinii krytyki o produktach kultury, ale samo w sobie nie zostało przez nią jasno zdefiniowane. Recenzję otwiera wstępna analiza tych konceptów, co z kolei pozwala autorowi poddać namysłowi dane prezentowane w książce. W podsumowaniu recenzent przedstawia konkluzje dotyczące obecnego stanu badań nad kulturą Europy Wschodniej, podkreślając ograniczenia oraz możliwe ścieżki rozwoju w tym zakresie. 